\title{
Reactions in Leprosy: an Epidemiological Study of 386 Patients in West Nepal
}

\author{
W. H. VAN BRAKEL, ${ }^{*} \ddagger$ ISHWAR B. KHAWAS $\dagger \&$ \\ SEBASTIAN B. LUCAS $\dagger$ \\ *Green Pastures Hospital, P.O. Box 28, Pokhara, Nepal; and \\ $\dagger$ Department of Histopathology, UCL Medical School, London, UK
}

\author{
Accepted for publication 28 February 1994
}

\begin{abstract}
Summary This paper presents epidemiological data on reversal reaction (RR) and erythema nodosum leprosum reaction (ENL) from a retrospective study of 386 leprosy patients newly registered at Green Pastures Hospital, Pokhara, West Nepal. The average follow-up time was 21 months. The prevalence of R R at first examination was $28 \%(23-32)$, and the prevalence of ENL reaction was $5 \cdot 7 \%$ $(2 \cdot 3-9 \cdot 2)$. The overall incidence rates among the 335 patients that were available for follow-up were $8 \cdot 7(6 \cdot 5-12) / 100$ person years at risk (PYAR) for RR and $3 \cdot 2$ $(1 \cdot 5-6 \cdot 7) / 100$ PYAR for ENL. Relapse of RR was common (1.4/patient). In all, $52 \%$ of R R were complicated by new nerve function impairment, against $59 \%$ of ENL reactions. The finding of other investigators that most RRs occur during the first year of treatment was confirmed by this study. The most significant risk factor for RR was extent of clinical disease measured by a count of body areas with clinical signs of leprosy. The risk of developing a R R for patients with 'extensive disease' ( 3 or more out of 9 body areas involved) was 10 times that of patients with limited disease (Rate Ratio 10 (1.3-76), $p=0 \cdot 026)$.

The study indicated that the following categories of patients in Nepal are at high or increased risk of developing a R R: 1, borderline patients during their first year of MDT; and 2, patients with more extensive clinical disease as described above.
\end{abstract}

\section{Introduction}

Although leprosy reactions are a very common phenomenon, very few data have been published on their epidemiology - the 5 publications by Duncan \& Pearson, ${ }^{1}$ BecxBleumink et al., ${ }^{2,3}$ Roche et al. ${ }^{4}$ and Lockwood et al. ${ }^{5}$ are notable exceptions. Up to now, no prospective studies have been published that were designed to establish the incidence rates of the various forms of leprosy reactions. The available epidemiological information is therefore still quite patchy and incomplete, despite a growing amount of literature on the treatment of reactions in leprosy. ${ }^{6-11}$ 
Green Pastures Hospital (GPH) is a 100-bed mission hospital in Pokhara, West Nepal, run by the International Nepal Fellowship under its Leprosy Control Project, which is a joint venture with His Majesty's Government/Nepal. GPH is the main leprosy referral hospital for the West of Nepal. Because of good record keeping combined with fairly constant methods of nerve function assessment, it was thought that the data thus accumulated would form a useful database for a retrospective study of reactions and peripheral neuropathy in leprosy. This paper discusses the prevalence and incidence of reversal reactions (RR) and ENL reactions (ENL). The significance of a third type of reaction, Silent Neuropathy, will be discussed in a separate paper. ${ }^{12} \mathrm{We}$ also attempted to analyse possible risk factors for RR.

\section{Methods}

STUDY QUESTIONS

1 What is the prevalence at registration and incidence of leprosy reactions (RR, ENL) in the study patient population?

2 Can any risk factors for RR and ENL be identified?

OUTCOME MEASURES

For question 1:

The number of patients with RR and ENL stratified by classification, severity of reaction, leprosy treatment and time of onset of reaction.

For question 2:

The association between leprosy reactions/neuritis and age, sex, classification, extent of disease (number of skin lesions, nerves and body areas involved in the disease), PGL-1 serology results, and type of leprosy treatment: MDT vs DDS monotherapy.

\section{CRITERIA FOR INCLUSION OF PATIENTS}

Only new, previously untreated patients who registered for treatment in GPH during the period January 1988-January 1992 were included in the study. Pure neuritic patients were excluded from the analysis, because our criteria for reaction were mainly based on skin signs.

\section{DIAGNOSIS AND CLASSIFICATION}

After registering at GPH, each patient was examined in the Outpatients Department by either of the 2 experienced leprosy supervisors. The examination included a full history, full body charting, palpation of all major peripheral nerve trunks and disability grading according to the 'old' WHO grading system $(0-3) .{ }^{13}$ Patients were classified according to the Ridley-Jopling system ${ }^{14}$ and our 'body area system' (PB/MB categories for treatment purposes), ${ }^{15}$ in which a patient with more than 2 out of 9 body areas is classified as multibacillary (MB).

If there was any doubt concerning the leprosy diagnosis, the classification, or 
whether the patient had had recent nerve function impairment (NFI), he was referred to the medical officer. In patients admitted to hospital their blood pressure and body weight were also recorded. The allocation of patients to MDT or DDS monotherapy regimens depended largely on whether a patient lived near enough to be able to attend for supervised treatment at least once every 2 months.

\section{HISTOLOGY}

From September 1990, all newly registered patients and all patients admitted for reaction and/or nerve function impairment treatment in GPH had a skin biopsy taken from an active lesion. Tissue was fixed in formalin, processed to paraffin and sections stained with haematoxylin and eosin and Wade-Fite stains. Histological classification of leprosy followed the standard Ridley-Jopling system. ${ }^{14}$

DIAGNOSIS OF REACTIONS AND NERVE FUNCTION IMPAIRMENT

REVERSAL REACTION (RR)

A patient was diagnosed as having a $\mathrm{RR}$ if he showed the following clinical signs:

Skin: redness and swelling of (usually already existing) lesions, sometimes tender in the lesions.

Nerves: often signs of neuritis: swelling, pain (shooting or burning), tenderness, paraesthesia or nerve function impairment.

General: sometimes oedema of hands, feet or face, occasionally fever.

The skin signs were obligatory; the nerve signs and general signs optional.

For this study, histopathology was not designed to contribute inclusion/exclusion criteria for RR. For both reversal and downgrading reactions, dermal oedema on skin histology was considered a feature. Positive features for a reversal (upgrading) reaction were increased numbers of large Langhans' giant cells, formation of discrete granulomas, epidermal erosion, fibrinoid necrosis of granulomas, and (for multibacillary leprosy patients) a reduction in the expected number of acid-fast bacilli. ${ }^{16,17}$

\section{ERYTHEMA NODOSUM LEPROSUM (ENL)}

A patient was diagnosed as having ENL if he showed the following clinical signs:

Skin: multiple, usually small, tender nodules, with or without ulceration, particularly on the arms and legs.

Nerves: often signs of neuritis: swelling, pain (shooting or burning), tenderness, paraesthesia or nerve function impairment.

General: fever, oedema, involvement of other organs, e.g. iritis, orchitis, arthritis.

The clinical diagnosis was supported by finding, on skin biopsy, multibacillary leprosy with an acute inflammatory cell infiltrate and oedema. ${ }^{16}$

SILENT NEUROPATHY (SN)

A patient was diagnosed as having $\mathrm{SN}$ if he showed the following clinical signs: evidence 
of recent (see below) sensory or motor nerve function impairment without skin signs of $\mathrm{RR}, \mathrm{ENL}$, obvious spontaneous nerve pain or nerve tenderness.

\section{NERVE FUNCTION IMPAIRMENT (NFI)}

A patient was considered to have NFI if there was a deterioration of $>2$ points in his VMT score, or 2 points or more in his TST score compared to the previous result. NFI of less than 6 months duration was recorded as 'recent', while NFI of longer duration was recorded as 'old'. If no previous VMT and TST results were available, the patient history regarding the onset of the muscle weakness and/or impairment of sensation was used to determine whether the nerve function impairment was 'recent' or 'old'.

The decision whether or not to initiate corticosteroid treatment for any given recent NFI was usually made by the medical officer, or, in his absence, by the nursing superintendent.

\section{NERVE FUNCTION ASSESSMENT}

NFA was done by either of 2 trained physiotechnicians over a period of 4 years at the following intervals: at the first examination, at every clinic visit for outpatients, at annual examinations during treatment and after release from treatment, every 2 weeks for patients receiving treatment for reaction or NFI.

\section{VOLUNTARY MUSCLE TEST (VMT)}

A full VMT was performed using the modified MRC scale as described by Brandsma. ${ }^{18}$ The VMT score $(0-5 ; 0=$ paralysed, $5=$ normal strength) consisted of the sum of 2 individual muscle scores for the ulnar, median, radial and lateral popliteal nerve (max. score 10 ). For the facial nerve only the orbicularis oculi muscle was tested (max. score 5).

\section{TOUCH SENSIBILITY TEST (TST)}

Touch sensibility of the ulnar and median nerves was tested on the palm of the hand using a nylon monofilament giving a force of approximately $10 \mathrm{gm}$ when pressed until it bent. The result was recorded as felt or not felt for each of the sites mentioned below. Touch sensibility of the posterior tibial nerve was tested in a similar way using a thicker monofilament, giving a force of about $75 \mathrm{gm}$. The TST score consisted of the sum of TST scores given for individual sites $(2=$ monofilament felt, $1=$ doubtful, $0=$ not felt $)$. We tested 3 sites for the ulnar nerve (max. score 6), 4 for the median (max. score 8 ) and 10 for the posterior tibial nerve (max. score 20 ).

\section{LABORATORY TESTS}

Serum of all patients was sent to the Mycobacterial Research Laboratory at Anandaban Hospital, Kathmandu, for ELISA testing of phenolic glycolipid-1 (PGL-1) antibody titres. The first (highest) result obtained was used for analysis. An absorbance of $>0 \cdot 199$ was considered positive. ${ }^{4}$ 


\section{STATISTICAL METHODS}

The significance of the difference between proportions was tested with using a Yatescorrected $\chi^{2}$ test or Fisher's exact test. The difference between 2 unpaired sample means was tested using the Student's $t$-test. For the calculation of the person years at risk denominator patients were censored as soon as they were diagnosed as having a RR. They were also censored from the denominator if they died, were transferred, or were otherwise lost to follow-up. Patients who had a reaction at registration were not excluded from the analysis, because they remained at risk of further reactions. The significance of various risk factors for reaction was examined with Cox's proportional hazards regression. The results are expressed as rate ratios. The adjusted rate ratio is the ratio obtained when age, sex, treatment, bacteriological index, PGL-1 status, and each of the extent-of-disease indicators in turn were entered together into the model. It may be interpreted as an estimate of the increase in risk associated with a particular risk factor after controlling for the other factors. A $p$-value of less than $5 \%$ was used as level of statistical significance. Of the prevalence, incidence rates and rate ratios the $95 \%$ confidence interval is given. For example, $4 \cdot 1(2 \cdot 1-8 \cdot 2)$ means that there is a $95 \%$ chance that the true value lies between $2 \cdot 1$ and $8 \cdot 2$. In computing the $95 \%$ confidence limits for rates a normal approximation was used if the number of observed reactions was 20 or more. For smaller numbers an exact method based on the Poisson distribution was used. Epi Info software, version $5.01^{19}$ and SPSS for Windows, version 6 were used for the analysis.

\section{Results}

\section{PATIENTS}

A total of 386 patients were included in the study - the mean age was 41 years (range 288 , standard deviation 16), and $70 \%$ were male. Only 335 patients were available for follow-up (the remainder was transferred after diagnosis). The average follow-up time of these patients at the start of data analysis was 20.7 months (range 1-49).

The distribution of the study patients according to the Ridley-Jopling classification was as follows. Two tuberculoid (TT), 202 borderline tuberculoid (BT), 7 borderline (BB), 133 borderline lepromatous (BL), and 42 lepromatous (LL).

\section{PREVALENCE}

Tables 1 and 2 show the prevalence and incidence rates of RR and ENL. The prevalence of RR was $28 \%$ at the time of diagnosis. For ENL this figure was $5 \cdot 7 \%$. In all categories more reactions were diagnosed at the start of treatment than during or after treatment. The distribution of prevalence over classification sub-groups is illustrated in Figure 1.

Of the BT patients who presented in reaction, 14 had a biopsy and 9 showed features of a RR. Of the BL patients who presented in reaction and were biopsied, 5/7 had histological features of RR with Langhans' giant cells (3 patients) and focalized granulomas (all 5 patients), in addition to the less specific dermal oedema. These were similar to the appearances of the biopsies taken from BL patients in reaction on MDT (which are, by definition, RR). 
Table 1. Prevalence and incidence rates of RRs among 386 new patients of leprosy at GPH

\begin{tabular}{|c|c|c|c|c|c|c|c|c|}
\hline \multirow[b]{2}{*}{ Classification } & \multicolumn{4}{|c|}{ Prevalence at registration } & \multicolumn{4}{|c|}{ Incidence rates } \\
\hline & Number & $\%(95 \% \mathrm{Cl})^{\mathrm{a}}$ & $\begin{array}{c}\text { Severe } \\
\text { reactions }\end{array}$ & $\begin{array}{l}\text { Reactions } \\
\text { with } \\
\text { new NFI }\end{array}$ & Number & $\begin{array}{l}\text { per } 100 \\
\text { PYAR }^{c}\end{array}$ & $\begin{array}{c}\text { Severe } \\
\text { reactions }\end{array}$ & $\begin{array}{c}\text { Reactions } \\
\text { with } \\
\text { new NFI }\end{array}$ \\
\hline TT & $0 / 2$ & 0 & 0 & 0 & $0 / 2$ & 0 & 0 & 0 \\
\hline BT & $69 / 202$ & $30(24-37)$ & $34 / 61$ & $30 / 61$ & $21 / 182$ & $6 \cdot 8(4 \cdot 4-10)$ & $11 / 21$ & $11 / 21$ \\
\hline BB & $2 / 7$ & $29(0-62)$ & $2 / 2$ & $2 / 2$ & $1 / 4$ & $20(2 \cdot 8-141)$ & $1 / 1$ & $1 / 1$ \\
\hline BL & $41 / 133$ & $31(23-39)$ & $21 / 41$ & $20 / 41$ & $23 / 106$ & $15(10-23)$ & $14 / 23$ & $14 / 23$ \\
\hline LL & $3 / 42$ & $7 \cdot 1(0-15)$ & $1 / 3$ & $1 / 3$ & $0 / 34$ & 0 & 0 & 0 \\
\hline Total & $107 / 386$ & $28(23-32)$ & $58 / 107$ & $53 / 107$ & $45 / 325^{d}$ & $8 \cdot 7(6 \cdot 5-12)$ & $26 / 45$ & $26 / 45$ \\
\hline
\end{tabular}

${ }^{a} 95 \%$ confidence interval, ${ }^{b}$ nerve function impairment, ${ }^{c}$ incidence expressed as the number of episodes of RR per 100 person years at risk (PYAR), ${ }^{d}$ the number of patients that was available for follow-up.

\section{INCIDENCE RATES}

The overall incidence rate of RR was 8.9/100 PYAR and 116 out of the 335 new patients who were followed up had a RR at registration or during or after treatment. Altogether, they had 160 episodes of reaction $(1 \cdot 4 /$ patient $)$. The incidence rate of ENL was $3 \cdot 2 / 100$ PYAR. The proportion of patients with severe reactions was $26 / 45(66 \%)$ and $7 / 7$ $(100 \%)$ in the RR and ENL groups, respectively. There was little difference in the severity of reactions between the classification sub-groups. shows the incidence rates of reaction in the different classification groups.

\section{TIME OF ONSET}

The occurrence of reactions by time of onset is shown in Figure 3 and Table 3. The great majority of RR that were diagnosed after the start of treatment occurred during the first 6 months of treatment (40/66); 4/12 ENL reactions occurred after the first year.

Table 2. Prevalence and incidence rates of erythema nodosum leprosum (ENL) among 175 new borderline lepromatous and lepromatous patients at GPH

\begin{tabular}{|c|c|c|c|c|c|c|c|c|}
\hline \multirow[b]{2}{*}{ Classification } & \multicolumn{4}{|c|}{ Prevalence at registration } & \multicolumn{4}{|c|}{ Incidence rates } \\
\hline & Number & $\%(95 \% \mathrm{Cl})^{\mathrm{a}}$ & $\begin{array}{c}\text { Severe } \\
\text { ENL }\end{array}$ & $\begin{array}{l}\text { ENL with } \\
\text { new NFI }\end{array}$ & Number & $\begin{array}{l}\text { per } 100 \\
\text { PYAR }^{c}\end{array}$ & $\begin{array}{c}\text { Severe } \\
\text { ENL }\end{array}$ & $\begin{array}{c}\text { ENL with } \\
\text { new NFI }\end{array}$ \\
\hline BL & $4 / 133$ & $3 \cdot 0(0 \cdot 1-5 \cdot 9)$ & $2 / 4$ & $1 / 4$ & $1 / 106$ & $0.58(0.08-4 \cdot 1)$ & $1 / 1$ & $1 / 1$ \\
\hline LL & $6 / 42$ & $14(3 \cdot 7-25)$ & $3 / 6$ & $3 / 6$ & $6 / 31$ & $13(5 \cdot 6-28)$ & $6 / 6$ & $5 / 6$ \\
\hline Total & $10 / 175$ & $5 \cdot 7(2 \cdot 3-9 \cdot 2)$ & $5 / 10$ & $4 / 10$ & $7 / 137^{d}$ & $3 \cdot 2(1 \cdot 5-6 \cdot 7)$ & $7 / 7$ & $6 / 7$ \\
\hline
\end{tabular}

\footnotetext{
${ }^{a} 95 \%$ confidence interval, ${ }^{b}$ nerve function impairment, ${ }^{c}$ incidence expressed as the number of episodes of
} ENL per 100 person years at risk (PYAR), ${ }^{d}$ the number of patients that was available for follow-up. 


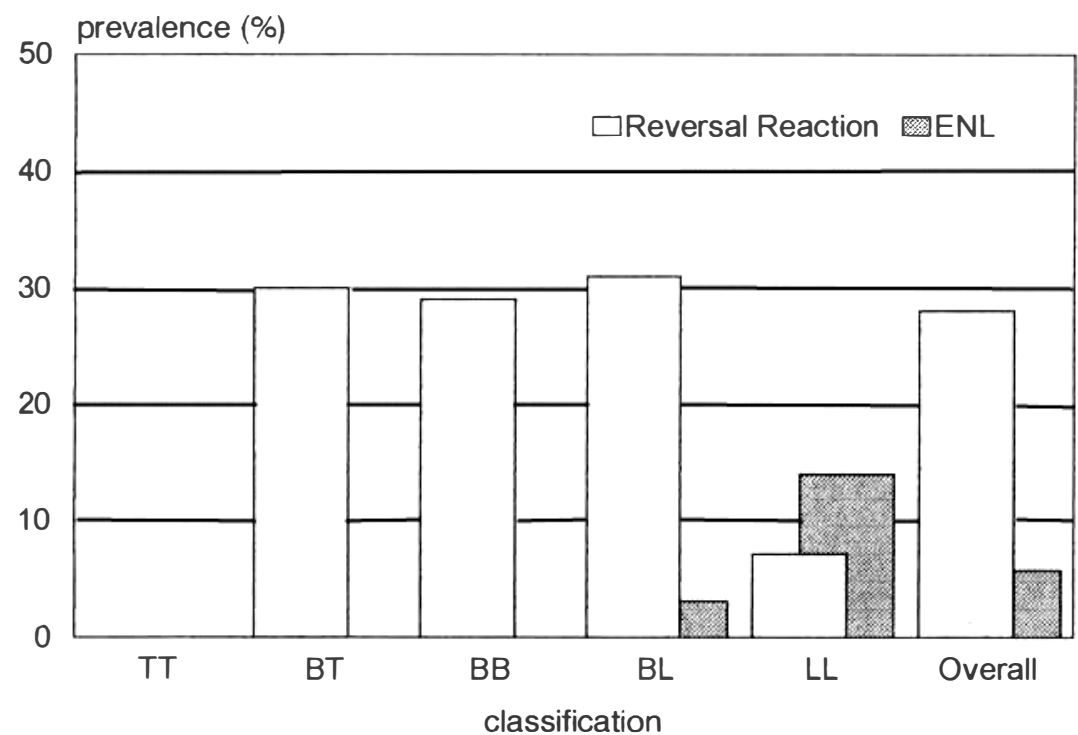

Figure 1. Prevalence of RR and ENL at the first examination in 386 new cases at GPH.

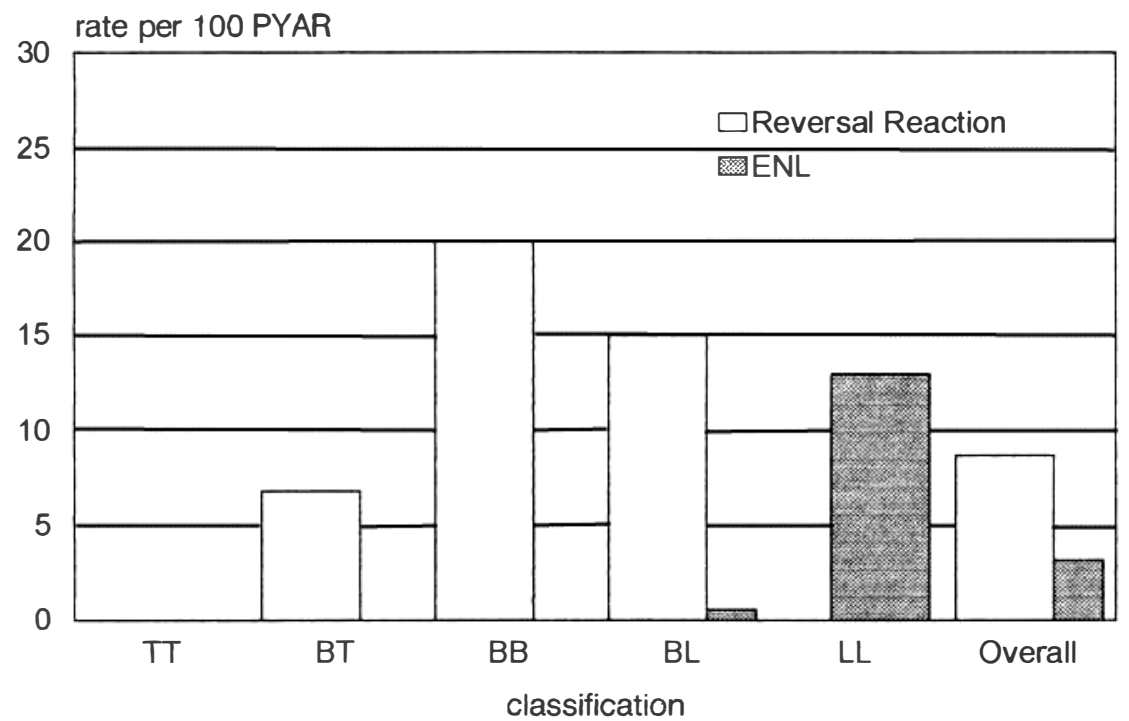

Figure 2. Incidence rates of RR and ENL per 100 person years at risk (PYAR) among 335 new patients at GPH. 


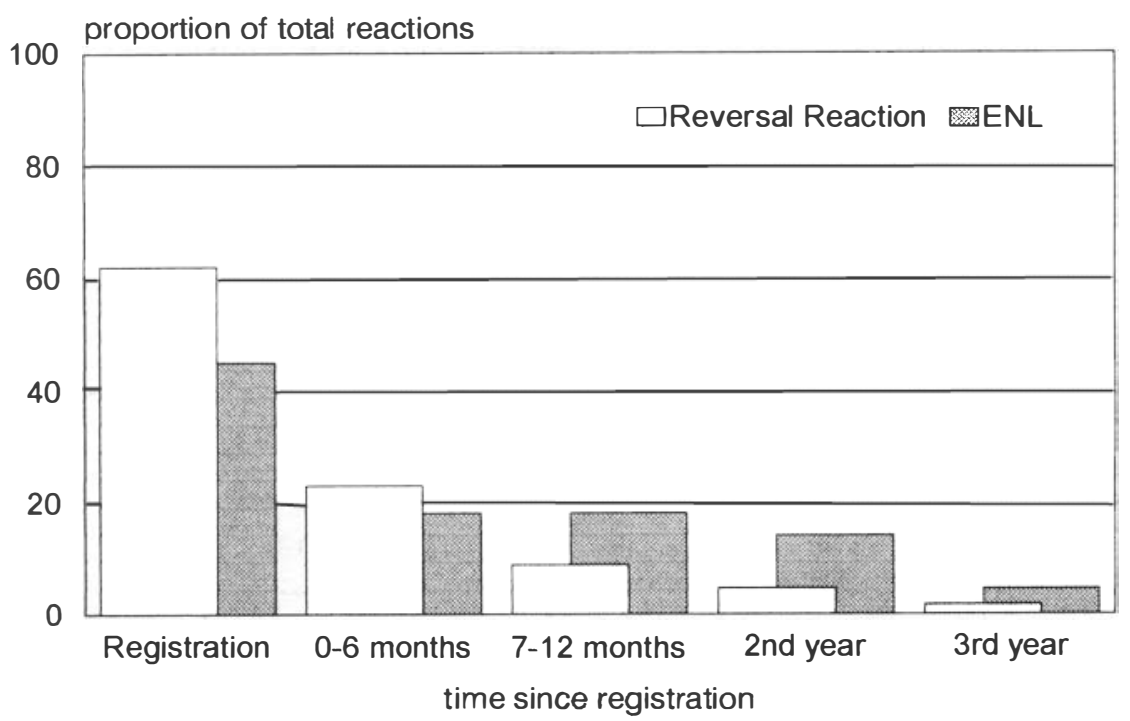

Figure 3. Occurrence of RRs and ENL by time of onset among new patients at GPH.

\section{RISK FACTORS}

The potential risk factors for RR and their significance is shown in Table 4. The skin lesion count was not an independent risk factor, but was strongly correlated to the body area count which was a stronger risk indicator. 'Extensive disease' was defined as: 3 or

Table 3. Occurrence of reactional episodes by time of onset among 384 new leprosy patients registered at GPH

\begin{tabular}{|c|c|c|c|c|c|c|c|c|}
\hline \multirow[b]{2}{*}{ Period } & \multicolumn{2}{|c|}{ BT } & \multicolumn{2}{|c|}{$\mathrm{BB}$} & \multicolumn{2}{|c|}{ BL } & \multicolumn{2}{|c|}{ LL } \\
\hline & number & $\%^{a}$ & number & $\%^{a}$ & number & $\%^{a}$ & number & $\%^{a}$ \\
\hline \multicolumn{9}{|l|}{ Reversal reactions } \\
\hline At registration & 61 & 69 & 2 & 66 & 41 & 53 & 3 & 100 \\
\hline $0-6$ months & 15 & 17 & 1 & 33 & 24 & 31 & & \\
\hline $7-12$ months & 7 & $7 \cdot 9$ & & & 8 & 10 & & \\
\hline 2nd year & 4 & $4 \cdot 5$ & & & 4 & $5 \cdot 1$ & & \\
\hline 3rd year & 2 & $2 \cdot 2$ & & & 1 & $1 \cdot 3$ & & \\
\hline Total & 89 & & 3 & & 78 & & 3 & \\
\hline \multicolumn{9}{|l|}{ ENL reactions } \\
\hline At registration & & & & & 4 & 40 & 6 & 50 \\
\hline $0-6$ months & & & & & 2 & 20 & 2 & 17 \\
\hline $7-12$ months & & & & & 2 & 20 & 2 & 17 \\
\hline 2nd year & & & & & 1 & 10 & 2 & 17 \\
\hline 3rd year & & & & & 1 & 10 & & \\
\hline Total & 0 & & 0 & & 10 & & 12 & \\
\hline
\end{tabular}

\footnotetext{
${ }^{\mathrm{a}}$ Column percentages.
} 
Table 4. Risk factors for RRs occurring after the start of antileprosy treatment among 335 new patients in GPH

\begin{tabular}{lccc}
\hline Risk factor & $\begin{array}{c}\text { Category of } \\
\text { patients }\end{array}$ & Rate ratio $^{\mathrm{a}}$ & $p$-value \\
\hline Sex & all & $1 \cdot 7(0 \cdot 85-3 \cdot 3)$ & $0 \cdot 14$ \\
& BT & $4 \cdot 7(1 \cdot 7-13)$ & $0 \cdot 0027$ \\
Treatment (MDT vs DDS) & all & $1 \cdot 7(0 \cdot 51-5 \cdot 5)$ & $0 \cdot 40$ \\
Extent of clinical disease & & & \\
$\quad>10$ skin lesions & all & $2 \cdot 8(1 \cdot 01-7 \cdot 5)$ & $0 \cdot 047$ \\
$\quad>3$ nerves enlarged & all & $1 \cdot 4(0 \cdot 51-3 \cdot 9)$ & $0 \cdot 51$ \\
$\quad$ 2 body areas involved & all & $10(1 \cdot 3-76)$ & $0 \cdot 026$ \\
Bacteriological index & all & $0 \cdot 76(0 \cdot 34-1 \cdot 7)$ & $0 \cdot 50$ \\
PGL-1 & BT & $1 \cdot 1(0.4-3 \cdot 3)$ & 0.80 \\
\hline
\end{tabular}

${ }^{a}$ Rate ratio adjusted for the influence of age, sex, treatment, bacteriological index, PGL-1 positivity, and each of the 3 indicators of extent of clinical disease in turn.

more out of 9 body areas with primary or secondary signs of leprosy, or more than 10 skin lesions, or more than 3 peripheral nerve trunks enlarged. A highly significant association was found between the risk of developing a RR and the extent of 'clinical' disease. The most effective indicator of 'extensive disease' was the body area count (rate ratio $10(1 \cdot 3-76))$. This finding will be discussed below in relation to its potential importance for the identification of patients at a risk of reaction. The incidence rate of reversal reaction in patients with 3 or more body areas involved was 10/100 PYAR. The rate among those with limited disease was approximately 1/100 PYAR. There was no significant difference in incidence of reaction between different age groups. Among BT patients, women had a significantly increased risk of developing reversal reaction (rate ratio $4 \cdot 7(1 \cdot 7-13), p=0 \cdot 0027)$. This sex difference in incidence rates was not significant in the whole patient group.

\section{Discussion}

Reversal reaction (RR), ENL, and what we have called silent neuropathy (SN) are the main causes of disabling nerve damage in leprosy. $\mathrm{SN}$ will be discussed in a separate paper. The main publications on occurrence of reactions are summarized in Table 5. To our knowledge, the present study is the first to present incidence rates of RR and ENL reaction in new patients. For the sake of comparison with other studies cumulative prevalence figures have been included in Table 5. It should be noted that cumulative prevalence figures can only be compared if they refer to an equal duration of follow-up.

\section{REVERSAL REACTIONS}

The impression of Pfaltzgraff \& Bryceson ${ }^{20}$ that more than $50 \%$ of BT patients develop a 
Table 5. Overview of publications on the occurrence of leprosy reactions

\begin{tabular}{|c|c|c|c|c|c|c|}
\hline \multirow[b]{2}{*}{ Author } & \multirow[b]{2}{*}{$\begin{array}{l}\text { Type of patients, average duration of } \\
\text { follow-up and classification }\end{array}$} & \multirow[b]{2}{*}{ Type } & \multicolumn{4}{|c|}{$\begin{array}{l}\text { Proportion of patients who developed a } \\
\text { reaction (year) }\end{array}$} \\
\hline & & & $\underset{\%}{\text { Registration }}$ & $\begin{array}{c}1 \\
(\%)\end{array}$ & $\begin{array}{c}2 \\
(\%)\end{array}$ & Cumulative $^{\mathrm{a}}$ \\
\hline $\begin{array}{l}\text { Pfaltzgraff \& } \\
\text { Bryceson }^{20}\end{array}$ & $\begin{array}{l}\text { type? follow-up? } \\
\text { BT } \\
\text { BB } \\
\text { BL } \\
\text { LL }\end{array}$ & $\begin{array}{l}\text { RR } \\
\text { RR } \\
\text { RR } \\
\text { ENL } \\
\text { ENL }\end{array}$ & & $\begin{array}{r}>50 \\
>50 \\
50\end{array}$ & & $\begin{array}{l}25 \\
50\end{array}$ \\
\hline $\begin{array}{l}\text { Rose } \& \\
\text { Waters }\end{array}$ & $\begin{array}{l}\text { all DDS patients, follow-up } 5 \text { years } \\
\text { BL } \\
\text { LLs }\end{array}$ & $\begin{array}{l}\text { RR } \\
\text { RR }\end{array}$ & & 33 & & $\begin{array}{l}50 \\
10\end{array}$ \\
\hline $\begin{array}{l}\text { Boerrigter } \\
\text { et } \text { al. }^{21}\end{array}$ & $\begin{array}{l}503 \text { field patients (new) } \\
\text { TT/BT }\end{array}$ & $\mathrm{RR}$ & $2 \cdot 2$ & $1 \cdot 4$ & $\begin{array}{l}3 \cdot 0^{\mathrm{b}, \mathrm{c}} \\
(7 \cdot 3)\end{array}$ & $\begin{array}{r}6 \cdot 6^{\mathrm{c}} \\
(8 \cdot 3)\end{array}$ \\
\hline $\begin{array}{l}\text { Groenen } \\
\text { et al. }\end{array}$ & $\begin{array}{l}\text { new }+ \text { old patients, follow-up: } \\
\text { max. } 3 \text { years (?) } \\
335 \text { PB } \\
280 \mathrm{MB}\end{array}$ & $\begin{array}{l}\text { RR } \\
\text { RR } \\
\text { ENL }\end{array}$ & & $\begin{array}{r}6 \\
48 \\
12\end{array}$ & & \\
\hline Roche $e t a l .^{4}$ & $\begin{array}{l}\text { New hospital out-patients, average } \\
\text { follow-up: } 21 \text { months (range } 7-35 \text { ) } \\
51 \mathrm{BT} \\
13 \mathrm{BB} \\
62 \mathrm{BL}\end{array}$ & $\begin{array}{l}\text { RR } \\
\text { RR } \\
\text { RR }\end{array}$ & & & & $\begin{array}{l}20 \\
46 \\
39\end{array}$ \\
\hline $\begin{array}{l}\text { Lockwood } \\
\text { et al. }\end{array}$ & $\begin{array}{l}\text { New hospital out-patients, follow-up: } \\
6 \text { years } \\
77 \text { TT } \\
218 \text { BT } \\
3 \text { BB } \\
67 \text { BL } \\
123 \mathrm{LL}\end{array}$ & $\begin{array}{l}\text { RR } \\
\text { RR } \\
\text { RR } \\
\text { RR } \\
\text { RR }\end{array}$ & & & & $\begin{array}{l}3 \cdot 8 \\
11 \\
100 \\
15 \\
2 \cdot 4\end{array}$ \\
\hline $\begin{array}{l}\text { Becx-Bleumink } \\
\& \text { Berhe }^{3}\end{array}$ & $\begin{array}{l}\text { New field patients, follow-up: } \\
24 \text { months } \\
438 \text { BT } \\
266 \text { BL } \\
109 \text { LL }\end{array}$ & $\begin{array}{l}\text { RR } \\
\text { RR } \\
\text { ENL } \\
\text { RR } \\
\text { ENL }\end{array}$ & $\begin{array}{l}3 \cdot 4 \\
4 \cdot 9 \\
0 \cdot 8 \\
0 \\
2 \cdot 8\end{array}$ & $\begin{array}{l}10^{\mathrm{b}} \\
26 \\
1 \cdot 1 \\
13 \\
5 \cdot 5\end{array}$ & $\begin{array}{l}7 \cdot 3^{\mathrm{b}} \\
12 \\
0 \cdot 8 \\
6 \cdot 4 \\
2 \cdot 8\end{array}$ & $\begin{array}{l}21 \\
44 \\
2 \cdot 7 \\
19 \\
11\end{array}$ \\
\hline $\begin{array}{l}\text { van Brakel } \\
\text { et al. }\end{array}$ & $\begin{array}{l}\text { New hospital out-patients, average } \\
\text { follow-up; } 21 \text { months (range } 1-49 \text { ) } \\
182 \mathrm{BT} \\
4 \mathrm{BB} \\
106 \mathrm{BL} \\
31 \mathrm{LL}\end{array}$ & $\begin{array}{l}\text { RR } \\
\text { RR } \\
\text { RR } \\
\text { ENL } \\
\text { RR } \\
\text { ENL }\end{array}$ & $\begin{array}{l}32 \\
50 \\
29 \\
1 \cdot 9 \\
6 \cdot 5 \\
16\end{array}$ & $\begin{array}{l}8 \cdot 2 \\
25 \\
13 \\
0 \\
0 \\
9 \cdot 7\end{array}$ & $\begin{array}{l}2 \cdot 2 \\
0 \\
3 \cdot 8 \\
0 \\
0 \\
6 \cdot 5\end{array}$ & $\begin{array}{l}39 \\
75 \\
38 \\
1 \cdot 9 \\
6 \cdot 5 \\
32\end{array}$ \\
\hline
\end{tabular}

${ }^{a}$ Cumulative prevalence of patients with a leprosy reaction. ${ }^{b}$ Actually, during PB MDT and during the first year after release from PB MDT. ${ }^{c}$ Refers to 'marked' RRs needing steroid treatment. The figure in parentheses includes also mild RRs. 
$\mathrm{RR}$ is not confirmed by more recent studies. Roche et al $^{4}$ and Becx-Bleumink \& Berhe ${ }^{3}$ report a cumulative percentage of about $20 \%$ in the BT group. The difference between their findings and ours $\left(20 \%\right.$ vs 36\%) may be explained by the fact that Roche et al. ${ }^{4}$ and Becx-Bleumink ${ }^{3}$ only included patients with severe reactions, while our figures include all reactions. Since only $55 \%$ of RR in our study were severe, the proportion of BT patients with severe reaction was about $21 \%$. The reactions described by Becx-Bleumink occurred among field patients and were therefore likely to be less common than among hospital outpatients like those in our study. This may also explain the difference in TT/ BT patients found by Boerrigter et al. ${ }^{21}$ and us (8.3\% vs 36\%). An ethnic difference may also be involved.

The high cumulative prevalence $(19 \%)$ of LL patients with RR found by BecxBleumink ${ }^{3}$ is surprising, particularly since only severe reactions were included. Rose \& Waters ${ }^{10}$ found $10 \%$ among LL patients treated with DDS over a 5 -year period, while we recorded only $7 \cdot 1 \%$ among 42 LL patients treated with MB MDT. An ethnic difference seems unlikely as in the other classification groups the trend is the reverse. A possible explanation would be that a number of patients that we would have classified as BL were classified as LL in the ALERT field programme. A low cumulative prevalence $(2 \cdot 4 \%)$ was found among 123 LL hospital outpatients in Hyderabad, India, during a 6-year follow-up period. ${ }^{5}$

Another difference between the Ethiopian data and our data is the proportion of RR present at the time of diagnosis (7.9\% vs 59\%). Most of our patients are self-reporting and therefore this indicates that RR was likely to be a reason for a patient to seek treatment, and even to go to a referral hospital rather than to a field clinic. This idea was already suggested by Naafs \& Wheate, ${ }^{22}$ reporting on Ethiopian hospital outpatients, who found that a large proportion of the reactions that occurred in BT/BB patients were present at the time of diagnosis $(62 \%)$. In the series described by Lockwood et al. ${ }^{5} 57 \%$ of reactions occurred before or at the time of first diagnosis. The finding of Naafs $\&$ Wheate ${ }^{21}$ that in BL patients the occurrence of RRs is spread out over a much longer period than in the BT/BB group is not confirmed by our data (see Table 3). This could be due to the fact that most of our patients were on MDT, while their patients were taking DDS monotherapy. The rapid bactericidal effect of rif ampicin may cause RRs to occur earlier in the course of treatment.

In the untreated BL patients, the nature of the reactions was not always clear. Some may have been downgrading, but by histological inference (they share features of paucibacillary patients and treated multibacillary patients in reversal reaction ${ }^{17}$ ), some were RR. There are no published studies that formally evaluate the sensitivity, specificity and predictive values of the proposed histopathological features of hypersensitivity reactions. ${ }^{17,23,24}$ Such an evaluation, with appropriate controls, is overdue.

\section{ENL REACTIONS}

ENL was relatively rare in both Ethiopian and Nepali BL patients $(2 \cdot 7 \%$ vs $1.9 \%)$. These figures are significantly lower than the $25 \%$ reported by Pfaltzgraff \& Bryceson. ${ }^{20}$ This is probably because of the protective effect of clofazimine against ENL. ${ }^{3}$ This would also explain the much lower ENL 'incidence' found in LL patients on MB MDT $(50 \% v s$ $11 \%$ and $32 \%$ ). The difference between Ethiopian and Nepali LL patients could again be due to the difference of field patients $v s$ hospital outpatients. 
The only risk factors that have been convincingly demonstrated are PGL-1 antibody 'positivity' and a positive lepromin test in borderline patients. ${ }^{4}$ Despite the fact that our patients' sera were analysed in the same laboratory at Anandaban Hospital in Kathmandu, our data did not confirm this finding. This is surprising since our patients matched those described by Roche et al. ${ }^{4}$ closely in terms of age and sex distribution. The explanation may be a difference in diagnostic criteria for RR. Roche et al. ${ }^{4}$ majored on the presence of (acute) neuritis, including neuritis without skin signs of RR. These criteria indicate that only more severe patients were included. We emphasized skin signs for the diagnosis ' $R R$ ', because these are the signs by which a RR is usually recognized and distinguished from ENL. But even modelling our data to include severe reactions only, also including $\mathrm{SN}$, or both, did not change the result.

Among our patients we found a consistently significant association between the extent of clinical disease, measured by the number body areas (out of 9) with clinical signs of leprosy, and the risk of developing a RR. A cut-off point of $3 / 9$, i.e. when a patient with $3 / 9$ or more body areas involved was classified as having 'extensive disease', showed a 10-fold increase in the risk of developing a R R when compared with patients with 'limited disease' (adjusted rate ratio 10, $p=0$.026). It could be argued that 'body areas' may just be a proxy indicator for bacteriological index or classification, i.e. that the risk of reaction increases towards the lepromatous end of the leprosy spectrum. However, a similar association was found within the BT patient subgroup (who were almost all skin smear negative), indicating that the body area count is a useful indicator of the risk of RR. We are not aware that this has been reported in the literature and submit that this finding, with its element of quantification (counting) is potentially of considerable importance for control programmes, for the identification of patients at risk of reaction. In programmes where workers are not familiar with body area counts a skin lesion count could be used as an indicator of the underlying risk factor, which is 'extensive disease'. Our data suggested more than 10 skin lesions' as the optimum cut-off point above which a patient should be classified as having 'extensive disease'.

In order to estimate the incidence rate among field patients, we calculated the rates for patients with extensive and with limited disease separately. Among 904 field patients newly registered by our Western Regional Mobile Clinic during 1990-92, 71\% had extensive disease. With a rate of 10/100 PYAR for these patients and 1/100 PYAR for patients with limited disease, the expected incidence rate of $R R$ in the field would be around 7/100 PYAR. In other words, 7 patients with RR out of every 100 per year. Similarly, a field programme with only $5 \%$ patients with extensive disease would have an estimated incidence rate of $1 \cdot 5 / 100$ PYAR.

We observed that in a number of patients a RR or ENL reaction that existed at the time of diagnosis got worse after the patient received the first dose of rifampicin. In a few patients an ENL relapse occurred every month 3-5 days after the patient had taken his or her monthly dose of MDT. Groenen et al. ${ }^{25}$ concluded from their study 'that rifampicin may enhance type 1 reactions ..., especially in previously untreated $\mathrm{MB}$ patients.' Our data were compatible with an increased risk of RR in patients on MB MDT as compared to patients on DDS, but this was not statistically significant. There was no difference in the proportion of severe reactions between the 2 treatment categories (data not shown). 
New potent bacteriocidal drugs or drug combinations should be caref ully tested to see if they produce an increased risk of reactions and or nerve damage. This is particularly true for regimens that will further reduce the duration of treatment and hence, potentially, the time of effective follow-up. This was expressed in the recent Consensus development statement on chemotherapy in leprosy. ${ }^{26}$ 'In evaluating any new treatment regimen, the incidence of disabilities during and after chemotherapy is as important a measure of the value of a new regimen as the relapse rate.'

It has been our policy to delay the first monthly dose of rifampicin if a patient presented with a reversal or ENL reaction (or SN) at the time of diagnosis (usually for only 1 month) until the reaction was under control.

The only other group that appeared to be at increased risk was female BT patients. An increased risk of RR may be expected in female patients of childbearing age, due to an increase of the cell-mediated immunity after delivery, triggering off upgrading reactions. ${ }^{1}$ The observed increase in risk is, therefore, probably not due to classification but by placing an increased proportion of women who had a recent delivery in this group. Information on pregnancy or lactation was unfortunately not recorded systematically. It was therefore not possible to check this assumption. None of the factors in Table 4 was significant as a risk factor for ENL reaction, but the numbers were very small.

\section{TREATMENT OF REACTIONS}

The treatment of reactions will not be discussed here. In most patients the important part is the treatment of the accompanying nerve function impairment. Patients with a mild reactions of any type (no nerve function impairment or involvement of other organs) were treated with a combination of aspirin and chloroquin. The patients (except women of childbearing age) with severe ENL were treated with thalidomide (starting dose $200 \mathrm{mg}$ twice daily). Women of childbearing age, as well as RR and SN patients with nerve function impairment, are treated with prednisolone, starting with $40 \mathrm{mg}$ od and gradually tapering every 2 weeks. The duration of the standard regimen is currently 16 weeks.

\section{Conclusions}

RR and ENL are common complications in Nepali leprosy patients, often leading to nerve function impairment.

Certain categories of patients appeared to be at high risk of developing a RR: 1, borderline patients during their first year of MDT; and 2, patients with extensive clinical disease (defined as $3 / 9$ or more body areas with clinical signs of leprosy). They should be monitored with great care, including a nerve function assessment at every clinic visit, at least during their first year of treatment with MDT.

\section{Acknowledgments}

We are grateful to the staff of GPH for their dedication in the treatment and care of patients with leprosy reactions. We are endebted to Professor F. G. I. Jennekens and Dr B. Naafs for their valuable and encouraging comments and suggestions for this 
manuscript, and to Mrs M. Hackett (supported by The Leprosy Mission) for providing histological expertise. Thanks be to God for His inspiration, without which the work at this hospital would never have started.

\section{References}

1 Duncan ME, Pearson JMH. Neuritis in pregnancy and lactation. Int $J$ Le pr, 1982; 50: 31-8.

2 Becx-Bleumink M, Berhe D, 'T Mannetje W. The management of nerve damage in the leprosy control services. Lepr Rev, 1990; 61: 1-11.

3 Becx-Bleumink M, Berhe D. Occurrence of reactions, their diagnosis and management in leprosy patients treated with multidrug therapy; experience in the Leprosy Control Program of the All Af rica Leprosy and Rehabilitation Training Centre (ALERT) in Ethiopia. Int J Lepr, 1992; 60: 173-84.

4 Roche PW, Theuvenet WJ, Britton WJ, Risk factors for type I reactions in borderline leprosy patients. Lancet, 1991; 338: 654-6.

5 Lockwood DNJ, Vinayakumar S, Stanley JMA, McAdam KPWL, Colston MJ. Clinical features and outcome of reversal (type 1) reactions in Hyderabad, India. Int J Lepr, 1993; 61: 8-15.

6 Naafs B, Pearson JMH, Baar AJM. A follow-up study of nerve lesions in leprosy during and af ter reaction using motor nerve conduction velocity. Int J Le pr, 1976; 44: 188-97.

7 Naafs B, Pearson JMH, Wheate HW. Reversal reaction: the prevention of permanent nerve damage. Comparison of short and long term steroid treatment. Int J Lepr, 1979; 47: 7-12.

8 Pearson JMH. The use of corticosteroids in leprosy. Lepr Rev, 1981; 52: 293-8.

9 Touw-Langendijk EMJ, Brandsma JW, Andersen JG. Treatment of ulnar and median nerve function loss in borderline leprosy. Lepr Rev, 1984; 55: 41-6.

10 Rose P, Waters MFR. Reversal Reactions in leprosy and their management. Le pr Rev, 1991; 62: 113-21.

11 Naafs B. Leprosy reactions. Quad Coop San, 1992; 12: 67-72.

12 van Brakel WH, Khawas IB. Silent neuropathy in leprosy: an epidemiological description. Lepr Rev, 65, in press.

13 WHO Expert Committee on leprosy, Fourth report. WHO Technical Report series. No. 459. WHO, Geneva, 1970.

14 Ridley DS, Jopling WH. Classification of leprosy according to immunity: a five group system. Int J Lepr, 1966; 34: 255-73.

15 van Brakel WH, de Soldenhoff R, McDougall AC. The allocation of leprosy patients into paucibacillary and multibacillary groups for multidrug therapy, taking into account the number of body areas affected by skin, or skin and nerve lesions. Lepr Rev, 1992; 63: 231-45.

16 Ridley DS. Skin Biopsy in Leprosy, 3rd edition. Ciba-Geigy Ltd, Basle, Switzerland, 1990.

17 Ridley DS, Radia KB. The histological course of reactions in borderline leprosy and their outcome. Int $J$ Lepr, 1981; 49: 383-92.

18 Brandsma W. Basic nerve function assessment in leprosy patients. Le pr Rev, 1981; 52: 161-70.

19 Dean AG, Dean JA, Dicker RC. Epi Info, Version 5: a word processing, database, and statistics program for epidemiology on microcomputers. USD, Inc., Stone Mountain, Georgia, 1990.

20 Pfaltzgraff RE, Bryceson A. Clinical leprosy. In: Hastings RC. (ed) Leprosy. Edinburgh: Churchill Livingstone, 1985.

21 Boerrigter, G, Ponnighaus JM, Fine PEM. Preliminary appraisal of a WHO-recommended multiple drug regimen in paucibacillary leprosy patients in Malwai. Int J Le pr, 1988; 56: 408-17.

22 Naafs B, Wheate HW. The time interval between the start of anti-leprosy treatment and the development of reactions in borderline patients. Lepr Rev, 1978; 49: 153-7.

23 Sehgal VN, Gautam RK, Koranne R V, Beohar PC. The histopathology of type I (lepra) and type II (ENL) reactions in leprosy. Ind $J$ Lepr, 1986; 58: 240-3.

${ }^{24}$ Lazaro-Medina A, Tianco EA, Avila JM. Additional markers for type I reactional states of borderline leprosy. Am J Dermato pathol, 1990; 12: 417-21.

25 Groenen G, Janssens L, Kayembe T, Nollet E, Coussens L, Pattyn SR. Prospective study on the relationship between intensive bactericidal therapy and leprosy reactions. Int J Lepr, 1986; 54: 236-44.

26 Consensus development statement on the chemotherapy of leprosy. ALM International, 1992. 